\section{The University of Michigan Library has} received a $\$ 1.25$ million grant from The Andrew Mellon Foundation to create an endowed conservation librarian position. The library is to receive $\$ 1$ million in endowment money from the foundation, which it will match by raising funds to create a $\$ 2$ million endowment within three years. The foundation will also provide $\$ 250,000$ in spendable funds to hire and support the conservation librarian for the first three years.

\section{The Institute for Advanced Technology in} the Humanities at the University of Virginia has partnered with the Northwest Digital Archives program of the Orbis Cascade Alliance to build, evaluate, and demonstrate the long-term viability of the Cross-Search and Context Utility (XCU). XCU will bring together digitized content from 36 systems at 25 institutions and detailed metadata from archival and manuscript collections at 33 institutions. The result will be access to digitized objects in the context of the collections to which they belong, greatly improving the presentation and usability of digital content and associated metadata, and better meeting the needs users. The project is funded with a $\$ 249,904$ National Leadership Grant from the Institute for Museum and Library Services.

\section{Penn State has received a $\mathbf{\$ 1 . 2 5}$ million}

grant from The Andrew W. Mellon Foundation to establish a new full-time senior conservator position in the university libraries. Based in the Department of Digitization and Preservation, the conservator will help to care for the libraries' extensive collections at all Penn State locations. A permanent endowment for the position will be established with $\$ 1$ million of the grant, and the libraries will raise an additional $\$ 1.25$ mil-

Ed. note: Send your news to: Grants \& Acquisitions, C\&RL News, 50 E. Huron St., Chicago, IL 60611-2795; e-mail: agalloway@ala.org. lion in matching support over three years. The remainder of the grant will support the position during the challenge period. The libraries will launch a national search for the senior conservator in the spring of 2013.

\section{Acquisitions}

\section{A collection of science fiction has been} gifted to San Diego State University's Love Library by Edward E. Marsh. Marsh has spent 30 years assembling this large collection, valued at more than $\$ 2.25$ million. The collection will eventually be displayed in the Edward Marsh Golden Age of Science Fiction Room, created specifically to house these works. Science fiction authors featured in the collection include Arthur C. Clarke, Robert Heinlein, Ray Bradbury, Isaac Asimov, Frank Herbert, L. Sprague de Camp, and Kevin Anderson, as well as classic science fiction by Jules Verne, H. G. Wells, and Edgar Rice Burroughs. Most of the books are signed first editions and include ephemera, such as press clippings, notes, and autographs. The collection also includes autographed photos, busts of authors, movie props, original artwork for book covers, literary contracts, portraits, and authors' yearbooks.

\section{The Congressional papers of U.S. Repre-} sentative Steven LaTourette (R-Painesville) have been acquired by Hiram College in Hiram, Ohio. The eight-term Capitol Hill veteran who retired from the House of Representatives in 2012 made the donation to Hiram College to ensure that the documents remain within the district for use by the people of Northeast Ohio. It is estimated that the LaTourette papers will result in 18 linear feet of materials. The congressman's personal papers will be closed until his death, and the other materials will remain closed until 15 years after he left office. $\boldsymbol{n}$ 